\title{
Can endemic parasitic diseases and/or vectors play a role in the COVID-19 pandemic?
}

\author{
Review \\ Article \\ Enas A Elsaftawy ${ }^{1,2}$, Rita M Wassef ${ }^{3}$, Noha M Amin ${ }^{1}$ \\ Departments of Medical Parasitology, Faculty of Medicine, Cairo University ${ }^{1}$, Armed Forces \\ College of Medicine ${ }^{2}$, Helwan University ${ }^{3}$, Cairo, Egypt
}

\begin{abstract}
COVID-19 is a novel single-stranded RNA virus responsible for the preliminary outbreak of viral pneumonia in China that progressed rapidly into a pandemic. To our knowledge, the possible benefits, or detriments of the co-existence of endemic parasitic infections and vectors, especially in the old world, haven't been considered. In this review, we aimed to introduce several inquiries in this concern.
\end{abstract}

Keywords: COVID-19; parasites; parasitic infections; vectors.

Received: 9 December, 2020, Accepted: 21 January, 2021.

Corresponding Author: Rita M Wassef, Tel.: +20 1005782994, E-mail: rita.wassef@med.helwan.edu.eg

Print ISSN: 1687-7942, Online ISSN: 2090-2646, Vol. 14, No. 1, April, 2021.

The novel coronavirus SARS-CoV-2 (COVID-19), a strain of severe acute respiratory syndromerelated coronavirus (SARSr-CoV), was first identified in December 2019 in Wuhan, the capital city of Hubei, China ${ }^{[1]}$.Transmission dynamics of COVID-19 depends chiefly on the respiratory droplets and the direct contact with infected subjects (carrier or diseased ${ }^{[2]}$. What prompted WHO to consider COVID-19 a serious infectious agent is the high infectivity and speedy development into a pandemic. Additionally is its potentiality to cause severe pneumonia and acute respiratory distress syndrome (ARDS), a matter that may progress into multi-organ dysfunction, and death in a few days to weeks in vulnerable subjects ${ }^{[3-5]}$. However, it is worth mentioning that it has a lower fatality ratio if compared with the two related epidemics; SARS-CoV-1 and Middle East respiratory syndrome (MERS)-CoV ${ }^{[6]}$. The COVID-19 condition progressed internationally to influence deeply the economies of different countries. The closure of borders and the shutdown policy of all nonessential activities was followed in China, Italy, and South Korea while other countries like Iran minimized the working hours ${ }^{[7]}$. Moreover, in a trial to minimize false negative results, even with quantitative PCR methods, prompt scientific research with a large budget settled for alternative serological diagnosis ${ }^{[8]}$. A second wave is present now a days in some countries with different protective measures worldwide ${ }^{[9]}$.

Theoretical data about COVID-19 from previous outbreaks of other coronaviruses suggested a solid collaborative role for type I interferon (IFN1), tumour necrosis factor- $\alpha$ (TNF- $\alpha$ ), and other cytokines in the viral immune response ${ }^{[10]}$ as illustrated in figure (1). As a consequence, pulmonary histological changes include bilateral diffuse alveolar damage; cellular fibromyxoid exudates; desquamation of pneumocytes; hyaline membrane formation signifying ARDS; and interstitial infiltrates of mononuclear inflammatory cells mainly lymphocytes in both lungs ${ }^{[11]}$. Moreover, it has extensive effects on all organs causing inflammation, vasoconstriction, hypercoagulability, and oedema. Deep venous thrombosis, embolism formation and disseminated intravascular coagulation as well as ischemic stroke and myocardial infarction were reported ${ }^{[12]}$.

It is worth mentioning that the epidemic of COVID-19 came in accordance with some antiparasitic elimination programs. For instance, in China, there has been counter measurements against emerging malaria infections ${ }^{[13]}$. Also, in Egypt, there were vast efforts to remodel the epidemic figure of hepatitis- $C$ virus ${ }^{[14,15]}$, besides the continual efforts to eliminate schistosomiasis ${ }^{[16,17]}$. Moreover, the endemicity of parasitic infections in millions of people in the old world was referred to in several parasitological and tropical surveillance studies and now populations are facing such a pandemic ${ }^{[18,19]}$.

With this concern in mind, we tried to relate the infectious problem of COVID-19 differently and to determine if there might be any hidden benefits from the endemicity of the parasitic infections and/ or vectors in some countries on this virus infection. For instance, could the immune-modulatory status in helminthic infections alleviate COVID-19? What about cross-reactivity? Can it accelerate herd immunity? Could COVID-19 simulate some parasitic infections in the route of infection and, what about the efficacy of the anti-parasitic therapeutic regimens in this pandemic? All these questions we tried to broach and discuss in this review.

\section{Can co-helminthic infections suppress immunity against COVID-19?}

Some parasites have the capacity to modulate the immune system to assure their longevity inside their hosts ${ }^{[20,21]}$. This process is chiefly observed in helminths across the three taxonomic categories 


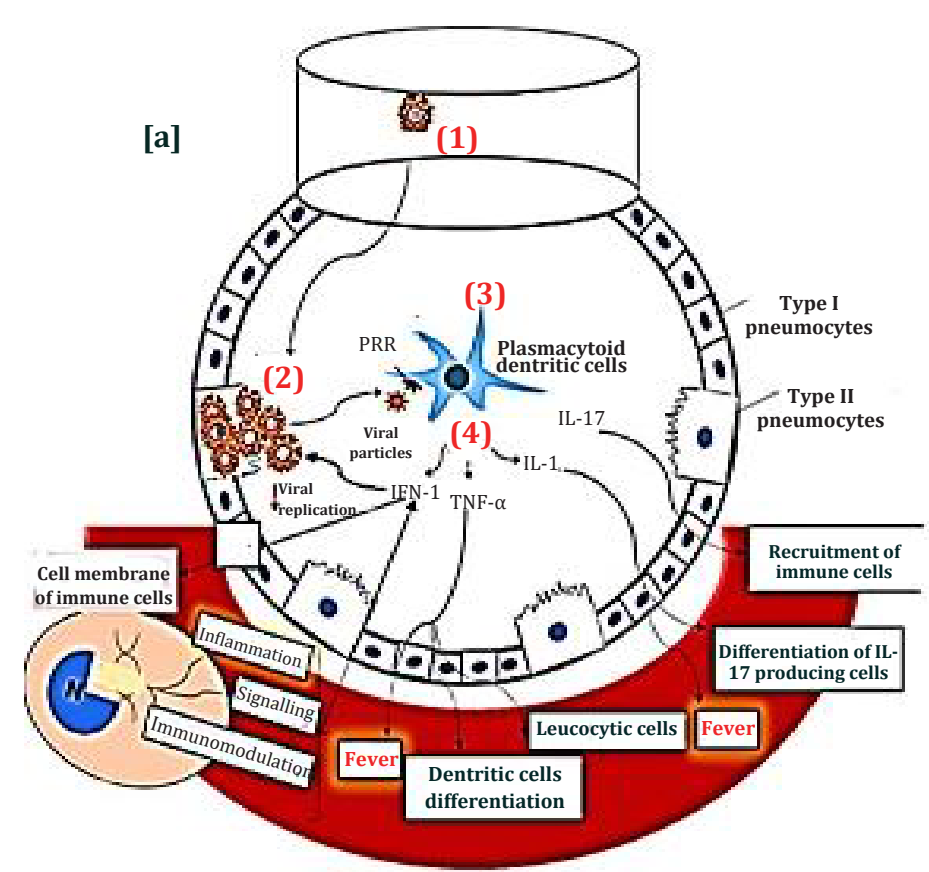

[b]
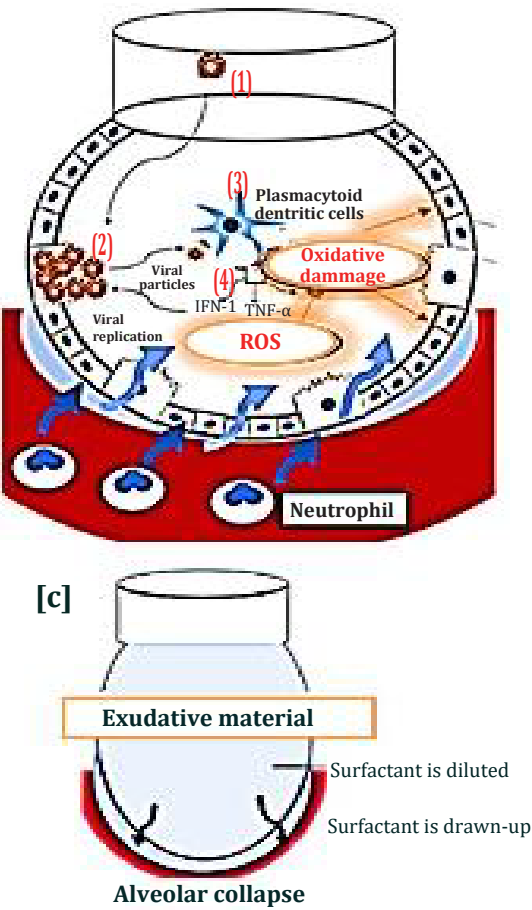

Fig. 1. COVID-19 alveolar damage. (a) COVID-19 gets attached to type-II pneumocytes to start cycles of intracytoplasmic replications. Dendritic cells recognize viral particles via pattern recognition receptors (PRR); hence in response it secretes interleukin (IL)-17 cytokines, IL-1, TNF- $\alpha$, and IFN-1 to mediate fever and to promote dendritic cell differentiation, and leukocyte recruitment; (b) neutrophil induced oxidative damage; (c) alveolar collapse. Illustrated by E. Elsaftawy.

(nematodes, cestodes, and trematodes) ${ }^{[22-26]}$. The elicited type- 2 responses suppress $\mathrm{T}$ helper-1 (Th1) cells. Also, the expanded populations of Th2 cells and alternatively activated macrophages direct the cytokine profiles towards IL-4, IL-5, IL-9, and IL-13. Helminths secrete immunomodulatory proteins that skew the production of IL-10 in addition to the extension of the regulatory $\mathrm{T}$ (Treg) cell and the regulatory $\mathrm{B}$ cells, and thus more inhibition occurs to type-1 responses ${ }^{[27-29]}$. Moreover, helminth-induced alterations of the gut microbiome also have systemic immunomodulatory effects $^{[30]}$ as illustrated in figure (2).

In these regards, prior studies demonstrated the possible therapeutic effects of helminthic infections in some autoimmune and allergic reactions ${ }^{[31,32]}$, and recently scientists questioned the possibility of helminthic co-infection to modulate the severity of COVID-19 ${ }^{[33]}$. Interestingly, in 2018 a study demonstrated that IL-4 response during helminth infections can increase antigen-specific CD8+ T cell effector responses in the lung that enhances control of viral infection ${ }^{[34]}$. Similarly, previous studies on animal models demonstrated the role of parasites against viral infections 'parasites against virus phenomenon' ${ }^{\text {[35] }}$. Trichinella spiralis and Nematospiroides dubius $(N$. dubius) were able to lessen the immune-pathological changes caused by influenza A virus. Pulmonary viral titres were less in $N$. dubius co-infection, and Heligmosomoides polygyrus infections attenuated pulmonary diseases after respiratory syncytial virus infection ${ }^{[36-38]}$. Protozoal infections were also observed

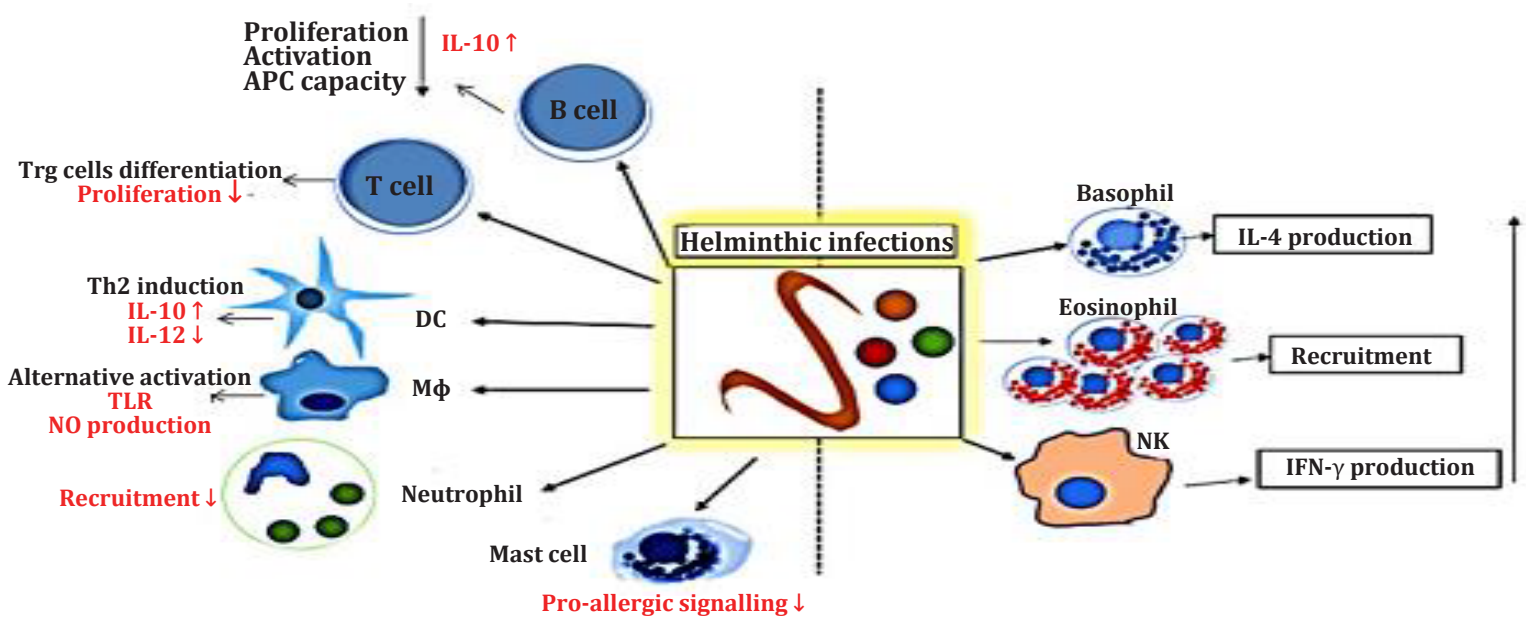

Fig. 2. Impact of helminthic infections on various immune cells. APC: Antigen presenting cell, DC: Dendritic cell; M $\boldsymbol{\text { : }}$ : Monocyte; NK: Natural killer cell; NO: Nitrous oxide; TLR: Toll like receptor. Illustrated by E. Elsaftawy. 
to modulate the severity of viral infections. Concurrent infection with $G$. lamblia reduces the severity of diarrheal episodes in rotaviruses ${ }^{[39]}$, in addition to the protective effect speculated between Plasmodium spp. and Chikungunya virus ${ }^{[40,41]}$. In this context, may passive immunization of COVID-19 patients with serum from subjects with prior parasitic infections improve their clinical outcomes?

It is to be noted that COVID-19 (SARS-CoV2) and other CoVs like HCoV-229E, HCoV-OC43, and MERS are characterized by being neurotropic ${ }^{[42-45]}$. In this concept, could COVID-19 invasion of the CNS be augmented by neurotropic protozoa? And to what extent can the pathology associated with these parasitic infections facilitate the invasion of the virus? Still a matter of research.

The CoVs can perform neuronal retrograde invasion to the CNS via the peripheral olfactory neuronal receptors, the trigeminal nerve in the nasal cavity, and sensory fibers of the vagus nerve in the brain stem ${ }^{[46-48]}$. However, COVID-19 requires angiotensin-converting enzyme- 2 receptors to invade the host cells. Therefore, the process of cerebral invasion by the virus appeared to be dependable on the sufficiency of this receptor in the $\mathrm{CNS}^{[49-51]}$. Herein, can we speculate that the co-existence of some unicellular eukaryotes, like $N$. fowler $i^{[52]}$ that possesses a similar route of infection, may encourage the invasion of the virus? Infectivity of $N$. fowleri trophozoites occurs through mucosal attachment in the nasal cavity, followed by locomotion along the olfactory nerve, then through the cribriform plate, to reach finally the olfactory bulbs within the CNS. The pathology related to $N$. fowleri is attributed to several factors: the significant innate immune response elicited upon residence of the parasite in the olfactory bulbs including macrophages and neutrophils; the food cups on the trophozoite surface that enable the parasite to ingest bacteria, fungi, and human tissue besides causing tissue destruction; and the release of cytolytic enzymes, e.g. acid hydrolases, phospholipases, neuraminidases, and phospholipolytic enzymes that destruct nerve cells ${ }^{[53-57]}$. Could these pathogeneses facilitate invasion of the virus?

The CoVs were also found to invade CNS via the hematogenous route to pass through the blood- brain barrier (BBB) by mechanisms that involve the transcytosis across brain microvascular endothelial cells; the direct infection of the endothelial (in BBB) or epithelial cells (in blood-CSF barrier); or intracellularly in a hidden manner by leukocytes ${ }^{[58]}$. Similarly, primary amoebic meningoencephalitis caused by Acanthamoeba spp. starts with the lower respiratory tract, then it crosses BBB and develops into encephalitis via a multifactorial process that includes parasite determinants in the form of adhesins, proteases, phospholipases; or host immune responses such as IL- $\alpha$, IL- $\beta$, TNF- $\alpha$, IFN- $\gamma$, and host cell apoptosis. Accordingly, this enhances the permeability of brain endothelial cells and disrupts BBB integrity ${ }^{[59-61]}$.

\section{Can the anti-parasitic therapeutic regimens be effective in this pandemic?}

Surprisingly, the routine anti-viral treatment achieved little success in COVID-19. Moreover, the pathological scenario in SARS CoV2 Corona virus appeared to simulate some parasites. For instance, similar to malaria, the virus targets the heme group (porphyry) in the RBCs releasing iron and depriving the body of oxygen with a dramatic increase in the cytokines $^{[62]}$. In this instance, can we consider SARS CoV2 Corona virus to possess similar pharmaceutical targets to malaria infection?

- Anti-malarial agents: The suggested impact of Hydroxychloroquine/chloroquine (HCQ/CQ), as regards to clinical settings, indicates that HCQ SARSCoV2 infection seems to protect against haemoglobin invasion simulating its action in malaria infection. It was observed that CQ interferes with the intracellular availability of free iron by raising the lysosomal $\mathrm{pH}$ and hinders the recycling of the ferritin receptors and thus depresses ferritin and iron uptake by hepatocytes, and iron remains bound to transferrin ${ }^{[63-66]}$. In addition, CQ derivatives are supposed to interfere with T-cell activation via hindering the major histocompatibility complex (MHC) class-II-antigen presentation and intracellular calcium signalling ${ }^{[67]}$. On the other hand, HCQ has deep anti-inflammatory effects that alleviate the cytokine storm characteristic for COVID-19[68,69]. Figure (3) illustrates the theoretical action of HCQ/CQ in COVID-19.

- Ivermectin: The FDA has approved the use of Ivermectin for inhibition of SARS-CoV-2 replication

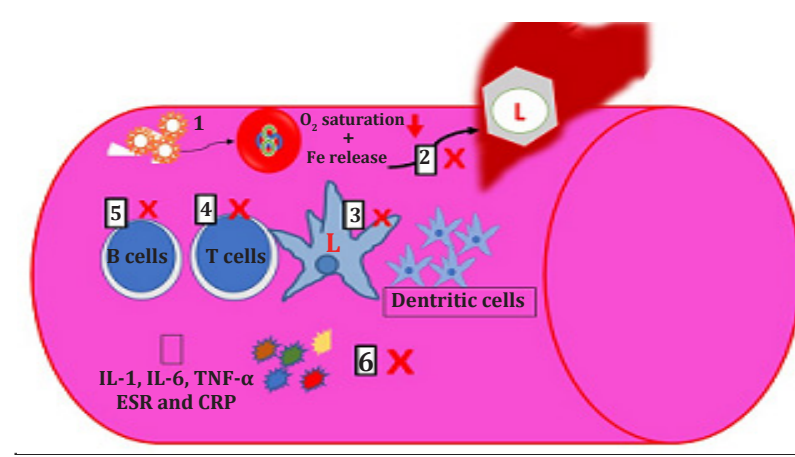

Fig. 3. The theoretical mode of action of HCQ/CQ compounds in COVID-19 (1) Hampering viral invasion to the heme group; (2) Inhibition of iron (Fe) uptake by the hepatocytes; (3) In the dendritic cells, they inhibit the signalling pathway of the toll-like receptors (TLR), raise the lysosomal $\mathrm{pH}$, inhibit proteolysis, hinder chemotaxis, antigen processing, and assembly of MHC- $\alpha$ and $-\beta$ chains of MHCs; (4) In the $T$ cells, they inhibit toll cell receptors (TCRs)-mediated intracellular calcium mobilization and suppress anti-TCRs-induced up-regulation of CD69 expression mandatory for T regulatory cell activation; (5) Inhibit TLR-mediated B cell functions, and (6) Exert immunomodulatory effect on the cytokine storm. Illustrated by $\mathrm{E}$. Elsaftawy. 
by $\sim 5000$-fold reduction at $48 \mathrm{~h}$ in vitro in cell culture. Ivermectin is adventitious for being widely available and included in the WHO model list of essential medications ${ }^{[70]}$. In addition, Patri and Fabbrocini ${ }^{[71]}$ recently inquired if HCQ and ivermectin can be used as a synergistic combination for COVID-19 chemoprophylaxis and/or treatment? In response, Bray et al. ${ }^{[72]}$ warned against using ivermectin in COVID-19 due to paucity of information regarding side effects.

- Can anti-Leishmania therapeutics be useful? $\mathrm{T}$ lymphocytes are assumed necessary for viral inactivation. However, it has been noticed that COVID-19 induces lymphopenia instead of lymphocytosis ${ }^{[73]}$ simulating visceral leishmaniasis ${ }^{[74]}$. Accordingly, could anti-leishmanial therapies re-establish the lymphocytic count? Prior studies revealed the positive impact of antimony on CD4+ counts ${ }^{[75-77]}$.

- Could patients' deworming programs add to the protection against COVID-19?: One study demonstrated that anti-helminthic therapy was associated with increases in CD4 counts and haemoglobin in addition to reduction in the viral load of HIV. However, its role in increasing the protection against COVID-19 is still not evaluated ${ }^{[78]}$.

Could cross reactivity of COVID-19 with endemic parasites share in the herd immunity against the new virus?

Once herd immunity has been established and the ability of the disease to spread is hindered, the disease can ultimately be eliminated. Immune individuals act as buffers between susceptible and infected subjects ${ }^{[79,80]}$. However, immunity must be developed through previous infections. Consequently, we wonder if there might be cross-reactivity between endemic parasitic infections and COVID-19. To which extent is the non-hygiene hypothesis beneficial in this regard, we do not know. However, previously researchers determined that exposure to a wide scale of germ antigens influences the building up of the immune system ${ }^{[81,82]}$.

What is the role of arthropods in COVID-19 transmission?

- Blood-sucking arthropods like mosquitoes as biological vectors in COVID-19: This may be considered if mosquitoes prove to be successful vectors in transmitting single stranded-RNA spherical viruses of the families Flaviviridae ${ }^{[83]}$. One report from Latin America inquired if mosquitoes (Aedes aegypti) can be a ticking time bomb to transmit COVID-19 especially since this geographical area suffered from the outbreak of ZIKA arboviral infection in the past few years. Moreover, the endemic dengue virus in Latin America transmittable by Ae. aegypti is difficult to distinguish from COVID-19 clinically and laboratorically ${ }^{[84-86]}$. In fact, some authors inquired about the possibility to analyse various insecticidal interventions to guard against mosquito bites and thus hinder the possible disease transmission ${ }^{[87]}$. Poinar ${ }^{[88]}$ suggested Culex tarsalis as a potential vector of COVID-19, since it is now a chief vector of West Nile virus, Western Equine encephalitis virus, and Saint Louis encephalitis virus in humans ${ }^{[88]}$. Although later the WHO declared that COVID-19 cannot be transmitted by mosquitoes and a recent experimental study proved failure of the virus to replicate in some widely distributed species of the mosquitoes, Ae. aegypti, Ae. albopictus and Culex quinquefasciatus ${ }^{[89]}$, however, the continuous mutation and changes in the structure of the virus may alter the interaction between the virus and different type of vectors. Therefore, more research is now mandatory to answer this question.

Another interesting point is the interactions between vectors and viruses which are still not well known. As noticed, the replication of flaviviruses and togaviruses in both insect and vertebrate hosts may accelerate the evolution into strains of varying virulence and host specificities $^{[90]}$. Example of this evolution has been documented with the West Nile virus that is transmitted by Culex pipiens mosquito ${ }^{[91]}$. This raises the question whether mutations are possible with COVID-19 upon interaction with different vectors.

\section{- Musca domestica and cockroaches for mechanical transmission of COVID-19: It was speculated that coronaviruses may be secreted in fecal material and different body secretions (respiratory secretions, saliva, and even semen ${ }^{[92-94]}$. It is worth mentioning that $M$. domestica and cockroaches were proved capable of mechanical transmission of other coronaviruses. Accordingly, low hygiene level and prevalence of $M$. domestica and cockroaches in the environment are strongly suggestive of widening transmission ${ }^{[95,96]}$.}

\section{Could parasitic infections increase morbidity in COVID-19?}

As regards the health reports of rural communities in the USA, co-infection with Ancylostoma duodenale may increase the severity of COVID-19 as it induces iron deficiency anaemia and reduces iron stores (ferritin) dramatically ${ }^{[97]}$, and thus adds to the disease caused by the iron release due to SARS-CoV2. On the other hand, co-infection with malaria could lead to worsening the outcome of disease caused by either of pathogens as both can induce a cytokine storm and coagulation state $^{[98]}$.

Are bats a common reservoir host for COVID-19 ${ }^{[99,100]}$
and parasitic infections?
Prior studies in China demonstrated the high
anti-Toxoplasma antibody titres in bats. Accordingly,
bats were suggested as novel and threatful hosts
for T. gondii ${ }^{[01-103]}$. Moreover, in vitro studies
speculated that T. gondii reactivates replication of
HIV (monotropic strain) via the induction of cytokine
secretion by macrophages ${ }^{[104]}$. It is worth mentioning


that ganciclovir which was initially integrated in the routine therapeutic regimen of COVID-19 can induce reactivation of Toxoplasma pneumonia ${ }^{[105-107]}$.

\section{Could parasites be infected with COVID-19 (endosymbiosis)?}

Recent studies showed that the genome of Acanthamoeba spp. is fertilized with DNA fragments of nucleocytoplasmic large DNA viruses ${ }^{[108]}$. Since Acanthamoeba infection can start as a lower respiratory tract infection, it is worth asking about the possibility of infection of this protozoon with SARS CoV 2 , the single-stranded RNA virus? Interestingly, many other protozoan parasites as Naegleria gruberi ${ }^{[109]}$, E. histolytica ${ }^{[110]}$, C. parvum $^{[111]}, \quad T$. vaginalis ${ }^{[12]}$, G. Iamblia $^{[113]}$, Eimeria stiedai ${ }^{[114]}$, Leishmania guyanensis ${ }^{[115]}$ and Plasmodium spp. ${ }^{[116]}$ were shown to be infected with double-stranded RNA viruses. These viruses, despite being incapable of causing direct infections in vertebrates, their genomes are sensed by the innate immunity of the host causing various inflammatory sequels ${ }^{[117]}$.

Conclusion: Endemicity of parasitic diseases, available anti-parasitic therapeutics, role of arthropods as well as reservoir hosts, and possibility of endosymbiosis may possess an obscure role in COVID-19 by either protection or morbidity increase. Close epidemiological studies are still required in this field.

Authors' contribution: All authors made substantial contributions to the manuscript; took part in drafting the article or revising it critically for important intellectual content and language editing; agreed to submit to the current journal; gave final approval of the version to be published; and agree to be accountable for all aspects of the work.

Declarations of interest: The authors declared that there were no potential conflicts of interest concerning the research, authorship, and/or publication of this article.

Financial support: This work did not receive any financial fund from any organization or institution.

\section{REFERENCES}

1. Song F, Shi N, Shan F, Zhang Z, Shen J, Lu H, et al. Emerging 2019 novel coronavirus (2019-nCoV) pneumonia. Radiology 2020, 295; 1:210-217.

2. World Health Organization. Modes of transmission of virus causing COVID-19: implications for IPC precaution recommendations: scientific brief, 27 March 2020

3. Zaim S, Chong JH, Sankaranarayanan V, Harky A. COVID-19 and multi-organ response. Curr Probl Cardiol 2020; 45(8):100618.

4. Epidemiology Working Group for NCIP Epidemic Response, Chinese Centre for Disease Control and Prevention. The epidemiological characteristics of an outbreak of 2019 novel coronavirus diseases (COVID-19), China, 2020. China CDC Weekly 2020; 2(8):113-122.

5. World Health Organization. Coronavirus disease (COVID-19), Geneva; 2019 (Situation report, 67).

6. Lai CC, Shih TP, Ko WC, Tang HJ, Hsueh PR. Severe acute respiratory syndrome coronavirus 2 (SARS-CoV-2) and coronavirus disease-2019 (COVID-19): The epidemic and the challenges. Int J Antimicrob Agents 2020; 55 (3):105924.

7. Onder G, Rezza G, Brusaferro S. Case-fatality rate, and characteristics of patients dying in relation to COVID-19 in Italy. JAMA 2020; 323(18):1775-1776.

8. Guo L, Ren L, Yang S, Xiao M, Chang D, Yang F, et al. Profiling early humoral response to diagnose novel coronavirus disease (COVID-19). Clin Infect Dis 2020; 71(15):778785.

9. Looi MK. Covid-19: Is a second wave hitting Europe? BMJ 2020; 371:m4113.

10. Mehta P, McAuley DF, Brown M, Sanchez E, Tattersall RS, Manson JJ. COVID-19: consider cytokine storm syndromes and immunosuppression. Lancet 2020. 395(10229):1033-1034.

11. Xu Z, Shi L, Wang Y, Zhang J, Huang L, Zhang C, et al. Pathological findings of COVID-19 associated with acute respiratory distress syndrome. Lancet Respir Med 2020; $8(4): 420-422$.

12. Jain U. Effect of COVID-19 on the organs. Cureus 2020; 12(8):e9540.

13. Zhu GD, Cao J. Challenges, and countermeasures on Chinese malaria elimination programme during the coronavirus disease 2019 (COVID-19) outbreak. Zhongguo xue xi chong bing fang zhi za zhi 2020; 32(1):79.

14. Omar H, El Akel W, Elbaz T, El Kassas M, Elsaeed K, El Shazly H, et al. Generic daclatasvir plus sofosbuvir, with or without ribavirin, in treatment of chronic hepatitis C: real world results from 18378 patients in Egypt. Aliment Pharmacol Ther 2018; 47(3):421-431.

15. Elgharably A, Gomaa AI, Crossey MM, Norsworthy PJ, Waked I, Taylor-Robinson SD. Hepatitis C in Egypt: past, present, and future. Int J Gen Med 2016; 10:1-6.

16. Elmorshedy H, Bergquist R, Fayed A, Guirguis W, AbdelGawwad E, Eissa S, et al. Elimination of schistosomiasis requires multifactorial diagnostics: evidence from highand low-prevalence areas in the Nile Delta, Egypt. Infect Dis Poverty 2020; 9:1-3.

17. Harris NL and Loke P. Recent advances in type-2-cellmediated immunity: insights from helminth infection. Immunity 2017; 47, 1024-1036.

18. Nozais JP. The origin and dispersion of human parasitic diseases in the Old World (Africa, Europe, and Madagascar). Mem Inst Oswaldo Cruz 2003; 98:13-19.

19. Xu LQ, Yu SH, Xu SH. Distribution, and pathogenic impact of human parasites in China. $1^{\text {st }}$ ed. 2002; People's Medical Publishing House, Bejing, China. 146-148.

20. World Health Organization. Coronavirus disease 2019 (COVID-19). Geneva; 2019 (Situation report, 72).

21. Remuzzi A, Remuzzi G. COVID-19 and Italy: what next? Lancet 2020; 395(10231):1225-1228. 
22. Cooper D, Eleftherianos I. Parasitic nematode immunomodulatory strategies: recent advances and perspectives. J Pathog 2016; 5(3):58.

23. Vendelova E, Lutz MB, Hrčková G. Immunity, and immune modulation elicited by the larval cestode Mesocestoides vogae and its products. Parasite Immunol 2015; 37(10):493-504.

24. Dautremepuits C, Betoulle S, Paris-Palacios S, Vernet G. Humoral immune factors modulated by copper and chitosan in healthy or parasitized carp (Cyprinus carpio L.) by Ptychobothrium sp. (Cestoda). Aquat toxicol 2004; 68(4):325-38

25. Wiedemann M, Voehringer D. Immunomodulation, and immune escape strategies of gastrointestinal helminths and schistosomes. Front Immunol 2020;11: 572865.

26. $\mathrm{Xu} \mathrm{Y,} \mathrm{Chen} \mathrm{W,} \mathrm{Bian} \mathrm{M,} \mathrm{Wang} \mathrm{X,} \mathrm{Sun} \mathrm{J,} \mathrm{Sun} \mathrm{H,} \mathrm{et} \mathrm{al.}$ Molecular characterization, and immune modulation properties of Clonorchis sinensis-derived RNASET2. Parasit Vectors 2013; 6(1):1-8.

27. Elliott DE, Summers RW, Weinstock JV. Helminths as governors of immune-mediated inflammation. Int J Parasitol 2007; 37:457-464.

28. Maizels RM, Balic A, Gomez-Escobar N, Nair M, Taylor $\mathrm{M}$, Allen JE. Helminth parasites: masters of regulation. Immunol Rev 2004; 201:89-116.

29. King CL, Medhat A, Malhotra I. Cytokine control of parasite-specific anergy in human urinary schistosomiasis. IL-10 modulates lymphocyte reactivity. J Immunol 1996; 156(12): 4715-4721.

30. Brosschot TP, Reynolds LA. The impact of a helminthmodified microbiome on host immunity. Mucosal Immunol 2018; 11:1039-1046.

31. Johnston MJG, Macdonald JA, McKay DM. Parasitic helminths: a pharmacopoeia of anti-inflammatory molecules. Parasitology 2008; 136(2):125-147.

32. Wilson MS, Taylor M, Balic A, Finney CAM, Lamb JR, Maizels RM. Suppression of allergic airway inflammation by helminth-induced regulatory T cells. J Exp Med 2005; 202:1199-1212.

33. Bradbury RS, Piedrafita D, Greenhill A, Mahanty S. Will helminth co-infection modulate COVID-19 severity in endemic regions? Nat Rev Immunol 2020; 20(6):342.

34. Rolot M, Dougall AM, Chetty A, Javaux J, Chen T, Xiao X, et al. Helminth-induced IL-4 expands bystander memory CD8+ T cells for early control of viral infection. Nat Commun 2018; 9(1):4516.

35. Shen SS, Qu XY, Zhang WZ, Li J, Lv ZY. Infection against infection: parasite antagonism against parasites, viruses, and bacteria. Infect Dis Poverty 2019; 8(1):49.

36. Chowaniec W, Wescott RB, Congdon LL. Interaction of Nematospiroides dubius and influenza virus in mice. Exp Parasitol 1972; 32:33-44.

37. Furze RC, Hussell T, Selkirk ME. Amelioration of influenza-induced pathology in mice by coinfection with Trichinella spiralis. Infect Immun 2006; 74:1924-1932.

38. McFarlane AJ, McSorley HJ, Davidson DJ, Fitch PM, Errington C, Mackenzie KJ et al. Enteric helminthinduced type I interferon signalling protects against pulmonary virus infection through interaction with the microbiota. J Allergy Clin Immunol 2017; 140:10681078.

39. Bilenko N, Levy A, Dagan R, Deckelbaum RJ, El-On Y, Fraser D. Does co-infection with Giardia lamblia modulate the clinical characteristics of enteric infections in young children? Eur J Epidemiol 2004; 19:877-8813.

40. Teo TH, Lum FM, Ghaffar K, Chan YH, Amrun SN, Tan JJL, et al. Plasmodium co-infection protects against Chikungunya virus-induced pathologies. Nat Commun 2018; 9:3905.

41. Teo TH, Howland SW, Claser C, Gun SY, Poh CM, Lee WW, et al. Co-infection with Chikungunya virus alters trafficking of pathogenic CD8 ${ }^{+} \mathrm{T}$ cells into the brain and prevents Plasmodium-induced neuropathology. EMBO Mol Med 2018; 10:121-138.

42. Conde G, Pájaro LD, Marzola ID, Villegas YR, Salazar LR. Neurotropism of SARS-CoV 2: Mechanisms and manifestations. J Neurol Sci 2020; 412:116824.

43. Xu J, Zhong S, Liu J, Li L, Li Y, Wu X, et al. Detection of severe acute respiratory syndrome coronavirus in the brain: potential role of the chemokine Mig in pathogenesis. Clin Infect Dis 2005; 41(8):1089-1096.

44. Gu J, Gong E, Zhang B, Zheng J, Gao Z, Zhong Y, et al. Multiple organ infection and the pathogenesis of SARS. J Exp Med 2005; 202(3):415-424.

45. Arabi YM, Harthi A, Hussein J, Bouchama A, Johani S, Hajeer AH, et al. Severe neurologic syndrome associated with Middle East respiratory syndrome Corona virus (MERS-CoV). Infection 2015; 43(4):495-501.

46. Siddell S, Wege $\mathrm{H}$, and Meulen V. The biology of coronaviruses. J Gen Virol 1983; 64:761-776.

47. Perlman S, Jacobsen G, Afifi A. Spread of a neurotropic murine coronavirus into the CNS via the trigeminal and olfactory nerves. Virology 1989; 170(2):556-560.

48. Barthold SW. Olfactory neural pathway in mouse hepatitis virus nasoencephalitis. Acta Neuropathol 1988; 76:502-506.

49. Hamming I, Timens W, Bulthuis ML, Lely AT, Navis G, van Goor $\mathrm{H}$, et al. Tissue distribution of ACE2 protein, the functional receptor for SARS coronavirus. A first step in understanding SARS pathogenesis. J Pathol 2004; 203:631-637.

50. Xu H, Zhong L, Deng J, Peng J, Dan H, Zeng X, et al. High expression of ACE2 receptor of 2019-nCoV on the epithelial cells of oral mucosa. Int J Oral Sci 2020; 12, 8.

51. Li W, Moore MJ, Vasilieva N, Sui J, Wong SK, Berne MA et al. Angiotensin-converting enzyme 2 is a functional receptor for the SARS coronavirus. Nature 2003; 426:450-454

52. CDC. Primary amebic meningoencephalitis associated with ritual nasal rinsing: St. Thomas, U.S. Virgin Islands, 2012. MMWR Morb Mortal Wkly Rep 2013; 62(45):903.

53. De Jonckheere JF. Origin and evolution of the worldwide distributed pathogenic amoeboflagellate Naegleria fowleri. Infect Genet Evol 2011; 11:1520-1528.

54. Jarolim KL, McCosh JK, Howard MJ, John DT. A light microscopy study of the migration of Naegleria fowleri from the nasal submucosa to the central nervous system during the early stage of primary amoebic 
meningoencephalitis in mice. J Parasitol 2000; 86:5055 .

55. Marciano-Cabral F, Cabral GA. The immune response to Naegleria fowleri amebae and pathogenesis of infection. FEMS Immunol Med Microbiol 2007; 51:243-259.

56. John DT, Cole TB Jr, Bruner RA. Amebostomes of Naegleria fowleri. J Protozool 1985; 32:12-19.

57. Visvesvara GS, Moura H, Schuster FL. Pathogenic and opportunistic free-living amoebae: Acanthamoeba spp., Balamuthia mandrillaris, Naegleria fowleri, and Sappinia diploidea. FEMS Immunol Med Microbiol 2007; 50(1):1-26.

58. Li YC, Bai WZ, Hashikawa T. The neuroinvasive potential of SARS-CoV2 may play a role in the respiratory failure of COVID-19 patients. J Med Virol 2020; 92(6):552-555.

59. Elsheikha HM, Khan NA. Protozoa traversal of the bloodbrain barrier to invade the central nervous system. FEMS Microbiol Rev 2010; 34(4): 532-553.

60. Alsam S, Kim KS, Stins M, Rivas AO, Sissons J, Khan NA. Acanthamoeba interactions with human brain microvascular endothelial cells. Microb Pathog 2003; 35(6):235-241.

61. Khan NA, Siddiqui R. Acanthamoeba affects the integrity of human brain microvascular endothelial cells and degrades the tight junction proteins. Int J Parasitol 2009; 39: 1611-1616.

62. Cavezzi A, Troiani E, Corrao S. COVID-19: hemoglobin, iron, and hypoxia beyond inflammation. A narrative review. Clin Pract 2020; 10(2):1271.

63. Cibille JC, Kondo H, Aisen P. Uptake of ferritin and iron bound to ferritin by rat hepatocytes: modulation by apotransferrin, iron chelators and chloroquine. Biochim Biophys Acta 1989; 1010(2):204-209.

64. Ramm GA, Powell LW, Halliday JW. Pathways of intracellular trafficking and release of ferritin by the liver in vivo: the effect of chloroquine and cytochalasin D. Hepatology 1994; 19(2):504-513.

65. Starke PE, Gilbertson JD, Farber JL. Lysosomal origin of the ferric iron required for cell killing by hydrogen peroxide. Biochem Biophys Res Commun 1985; 133: 371-379.

66. Newman SL, Gootee L, Brunner G, Deepe GS Jr. Chloroquine induces human macrophage killing of Histoplasma capsulatum by limiting the availability of intracellular iron and is therapeutic in a murine model of histoplasmosis. J Clin Invest 1994; 93: 1422-1429.

67. Goldman FD, Gilman AL, Hollenback C, Kato RM, Premack BA, Rawlings DJ. Hydroxychloroquine inhibits calcium signals in T cells: a new mechanism to explain its immunomodulatory properties. Blood 2000; 95(11):3460-3466.

68. Ye Q Wang B, Mao J. The pathogenesis and treatment of the cytokine storm' in COVID-19. J Infect 2020; 80(6):607-613.

69. Karres I, Kremer JP, Dietl I, Steckholzer U, Jochum M, Ertel W. Chloroquine inhibits pro-inflammatory cytokine release into human whole blood. Am J Physiol Regul Integr Comp Physiol 1998; 274(4): R1058-1064.

70. Caly L, Druce JD, Catton MG, Jans DA, Wagstaff KM. The FDA-approved drug ivermectin inhibits the replication of SARS-CoV-2 in vitro. Antiviral Res 2020; 178:104787.
71. Patrì A, Fabbrocini G. Hydroxychloroquine and ivermectin: A synergistic combination for COVID-19 chemoprophylaxis and treatment? J Am Acad Dermatol 2020; 82(6): e221.

72. Bray M, Rayner C, Noël F, Jans D, Wagstaff K. Ivermectin and COVID-19: a report in antiviral research, widespread interest, an FDA warning, two letters to the editor and the authors' responses. Antiviral Res 2020; 178:104805.

73. Tan L, Wang Q Zhang D, Wu YF, Guo D, Qin G, et al. Lymphopenia predicts disease severity of COVID-19: A descriptive and predictive study. Signal Transduct Target Ther 2020; 5(1):33.

74. Wortmann GW, Aronson NE, Byrd JC, Grever MR, Oster CN. Herpes zoster and lymphopenia associated with sodium stibogluconate therapy for cutaneous leishmaniasis. Clin Infect Dis 1998; 27(3):509-512.

75. Koech DK. Subpopulations of T lymphocytes in Kenyan patients with visceral leishmaniasis. Am J Trop Med Hyg 1987; 36(3):497-500.

76. Rohtagi A, Agarwal SK, Bose M, Chattopadhya D, Saha K. Blood, bone marrow and splenic lymphocyte subset profiles in Indian visceral leishmaniasis. Trans R Soc Trop Med Hyg 1996; 90(4):431-434.

77. Cenini P, Berhe N, Hailu A, McGinnes K, Frommel D. Mononuclear cell subpopulations and cytokine levels in human visceral leishmaniasis before and after chemotherapy. J Infect Dis 1993; 168(4):986-993.

78. Maumus F, Blanc G. Study of gene trafficking between Acanthamoeba and giant viruses suggests an undiscovered family of amoeba-infecting viruses. Genome Biol Evol 2016; 8(11):3351-3363.

79. Bulchandani VB, Shivam S, MoudgalyaS, Sondhi SL. Digital herd immunity and COVID-19. arXiv:2004.07237v2. https://arxiv.org/abs/2004.07237. Last update on 26 May 2020.

80. Kwok KO, Lai F, Wei WI, Wong SYS, Tang JWT. Herd immunity: estimating the level required to halt the COVID-19 epidemics in affected countries. J Infect 2020; 80(6): e32-e33.

81. Briggs N, Weatherhead J, Sastry KJ, Hotez PJ. The hygiene hypothesis and its inconvenient truths about helminth infections. PLoS Negl Trop Dis 2016; 10(9): e0004944.

82. Rook GAW. Introduction: the changing microbial environment, Darwinian medicine, and the hygiene hypothesis. In: The Hygiene Hypothesis and Darwinian Medicine. Birkhäuser Basel; 2009; 1-27.

83. Foster WA, Walker ED. Mosquitoes (Culicidae). In: Mullen GR, Durden LA. Medical and Veterinary Entomology, Second Edition, Oxford, Elsevier; 2009; 207-260.

84. Chen N, Zhou M, Dong X, Qu J, Gong F, Han Y, et al. Epidemiological and clinical characteristics of 99 cases of 2019 novel coronavirus pneumonia in Wuhan, China: A descriptive study. Lancet 2020; 395(10223):507-513.

85. Yan G, Pang L, Cook AR, Ho HJ, Win MS, Khoo AL, et al. Distinguishing Zika and dengue viruses through simple clinical assessment, Singapore. J Emerg Infect Dis 2018. 24(8):1565.

86. Yan G, Lee CK, Lam LT, Yan B, Chua YX, Lim AY, et al. Covert COVID-19 and false-positive dengue serology in Singapore. Lancet Infect Dis 2020; 20(5):536. 
87. Jindal A, Rao S. Lockdowns to contain COVID-19 increase risk and severity of mosquito-borne disease outbreaks. medRxiv 2020. https://www.medrxiv.org/content/10.1 101/2020.04.11.20061143v1. Last update on 17 April, 2020.

88. Poinar G. Could arthropod vectors play a role in the spread of COVID-19? Biosis: Biological Systems 2020; 1(2):91-93.

89. Huang YS, Vanlandingham DL, Bilyeu AN, Sharp HM, Hettenbach SM, Higgs S. SARS-CoV-2 failure to infect or replicate in mosquitoes: an extreme challenge. Sci Rep 2020; 10(1):11915.

90. Grimley PM. Togaviridae and Flaviviridae. In atlas of invertebrate viruses. CRC Press, 2017; 461-497.

91. Kilpatrick AM, Meola MA, Moudy RM, Kramer LD. Temperature, viral genetics, and the transmission of West Nile virus by Culex pipiens mosquitoes. PLoS Pathog 2008; 27; 4(6): e1000092.

92. Kassiri H, Akbarzadeh K, Ghaderi A. Isolation of pathogenic bacteria on the house fly, Musca domestica L. (Diptera: Muscidae), body surface in Ahwaz Hospitals, Southwestern Iran. Asian Pac J Trop Biomed 2012; 2(2): S1116-1119.

93. Ivers LC, Walton DA. COVID-19: Global health equity in pandemic response. Am J Trop Med Hyg 2020; 102(6):1149-1150.

94. Song C, Wang Y, Li W, Hu B, Chen G, Xia P, et al. Absence of 2019 novel coronavirus in semen and testes of COVID-19 Patients. Biol Reprod 2020; 103(1):4-6.

95. Dehghani R, Kassiri H. A brief review on the possible role of houseflies and cockroaches in the mechanical transmission of coronavirus disease 2019 (COVID-19) Arch Clin Infect Dis 2020; 15: e102863.

96. Calibeo-Hayes D, Denning SS, Stringham SM, Guy JS, Smith LG, Watson DW. Mechanical transmission of turkey coronavirus by domestic houseflies (Musca domestica Linnaeaus). Avian Dis 2003;47(1):149-153.

97. Gutman JR, Lucchi NW, Cantey PT, Steinhardt LC, Samuels AM, Kamb ML, et al. Malaria and parasitic neglected tropical diseases: potential syndemics with COVID-19? Am J Trop Med Hyg 2020; 103(2):572-577.

98. Calisher CH, Childs JE, Field HE, Holmes KV, Schountz T. Bats: important reservoir hosts of emerging viruses. Clin Microbiol Rev 2006; 19(3):531-545.

99. Ren LL, Wang YM, Wu ZQ, Xiang ZC, Guo L, Xu T, et al. Identification of a novel coronavirus causing severe pneumonia in human: a descriptive study. Chin Med J (Engl) 2020; 133(9):1015-1024.

100. Yuan ZG, Luo SJ, Dubey JP, Zhou DH, Zhu YP, He Y, et al. Serological evidence of Toxoplasma gondii infection in five species of bats in China. Vector Borne Zoonotic Dis 2013; 13(6):422-424.

101. Jiang $\mathrm{HH}, \mathrm{Qin} \mathrm{SY}$, Wang W, He B, Hu TS, Wu JM, et al. Prevalence and genetic characterization of Toxoplasma gondii infection in bats in southern China. Vet Parasitol 2014; 203(3-4):318-321.

102. Qin SY, Cong W, Liu Y, Li N, Wang ZD, Zhang FK, et al. Molecular detection, and genotypic characterization of Toxoplasma gondii infection in bats in four provinces of China. Parasit Vectors 2014; 7(1):558.
103. Bala S, Englund G, Kovacs J, Wahl L, Martin M, Sher A, et al. Toxoplasma gondii soluble products induce cytokine secretion by macrophages and potentiate in vitro replication of a monotropic strain of HIV. J Eukaryot Microbiol 1994;41(5):7S.

104. Banister S, Pomeroy C. Effect of ganciclovir on murine cytomegalovirus-induced reactivation of Toxoplasma pneumonia. J Lab Clin Med 1993; 122(5):576-580.

105. Li F, Cai J, Dong N. First cases of COVID-19 in heart transplantation from China. J Heart Lung Transplant 2020; 39:418-419.

106. Jockusch S, Tao C, Li X, Anderson TK, Chien M, Kumar $\mathrm{S}$, et al. Library of nucleotide analogues terminate RNA synthesis catalyzed by polymerases of coronaviruses causing SARS and COVID-19. Antiviral Res 2020; 180: 104857.

107. Ivan E, Crowther NJ, Mutimura E, Rucogoza A, Janssen $\mathrm{S}$, Njunwa KK, et al. Effect of deworming on disease progression markers in HIV-1-infected pregnant women on antiretroviral therapy: A longitudinal observational study from Rwanda. Clin Infect Dis 2015; 60(1):135-142.

108. Aherfi S, Colson P, La Scola B, Raoult D. Giant viruses of amoebas: an update. Front Microbiol 2016; 7:349.

109. Schuster FL. Intranuclear virus like bodies in the amoeboflageliate Naegleria gruberi. J Protozool 1969;16 (4): 724-727.

110. Mattern CF, Diamond LS, DanielWA.Viruses of Entamoeba histolytica II. Morphogenesis of the polyhedral particle (ABRM2 $\rightarrow$ HK-9) $\rightarrow$ HB-301 and the filamentous agent (ABRM2 $\rightarrow$ HK-9). Virology 1972; 9(2):342-358.

111. Khramtsov NV, Woods KM, Nesterenko MV, Dykstra CC, Upton SJ. Virus-like, double-stranded RNAs in the parasitic protozoan Cryptosporidium parvum. Mol Microbiol 1997; 26(2):289-300.

112. Parent KN, Takagi Y, Cardone G, Olson NH, Ericsson M, Yang $\mathrm{M}$, et al. Structure of a protozoan virus from the human genitourinary parasite Trichomonas vaginalis. mBio 2013; 4(2): e00056-13.

113. Janssen ME, Takagi Y, Parent KN, Cardone G, Nibert ML, Baker TS. Three-dimensional structure of a protozoal double-stranded RNA virus that infects the enteric pathogen Giardia lamblia. J Virol 2015; 89(2):11821194.

114. Xin C, Wu B, Li J, Gong P, Yang J, Li H, et al. Complete genome sequence and evolution analysis of Eimeria stiedai RNA virus 1, a novel member of the family Totiviridae. Arch Virol 2016; 161(12):3571-3576.

115. Bourreau E, Ginouves M, Prévot G, Hartley MA, Gangneux JP, Robert-Gangneux F, et al. Presence of Leishmania RNA virus 1 in Leishmania guyanensis increases the risk of first-line treatment failure and symptomatic relapse. J Infect Dis 2016; 213(1):105-111.

116. Rosenke K, Adjemian J, Munster VJ, Marzi A, Falzarano $\mathrm{D}$, Onyango CO, et al. Plasmodium parasitemia associated with increased survival in Ebola virus-infected patients. Clin Infect Dis 2016; 63(8):1026-1033.

117. Griffiths EC, Pedersen AB, Fenton A, Petchey OL. The nature and consequences of coinfection in humans. J Infect 2011; 63(3):200-206. 